\title{
Article
}

\section{Transformation of Business Models in Spa Enterprises for Medical Purposes in Situations of Epidemic Threats}

\author{
Adam R. Szromek \\ Department of Organization and Management, Institute of Economy and Informatics, \\ Silesian University of Technology, 44-100 Gliwice, Poland; szromek@polsl.pl
}

check for

updates

Citation: Szromek, A.R

Transformation of Business Models in Spa Enterprises for Medical Purposes in Situations of Epidemic Threats. J. Open Innov. Technol. Mark. Complex. 2021, 7, 143. https://doi.org/ 10.3390/joitmc7020143

Received: 22 April 2021

Accepted: 24 May 2021

Published: 25 May 2021

Publisher's Note: MDPI stays neutral with regard to jurisdictional claims in published maps and institutional affiliations.

Copyright: (C) 2021 by the author. Licensee MDPI, Basel, Switzerland. This article is an open access article distributed under the terms and conditions of the Creative Commons Attribution (CC BY) license (https:/ / creativecommons.org/licenses/by/ $4.0 /)$.

\begin{abstract}
The suspension of tourism due to the COVID-19 pandemic has led to an almost complete halt in the activities of the tourism industry. This paper attempts to assess the ability to use the potential of health tourism enterprises in counteracting the SARS-CoV-2 virus pandemic and to propose a sustainable transformation of the business model of the health tourism enterprise, taking into account the determinants of sustainable tourism and health crises. The author presents the results of research conducted in March 2021 among 19 managers of the largest spa enterprises in Poland. The managers' experiences from the first year of the COVID-19 pandemic indicate that sanatoriums and other health tourism facilities, during periods of health and humanitarian crises, can successfully play a preventive and relieving role for healthcare facilities by implementing post-COVID treatment, conducting vaccinations, organizing isolators for people in quarantine, and even treating patients who do not have symptoms but require hospitalization. The transformation of the business model of these companies, in the form of a sustainable SusHT-CANVAS+ business model, is proposed and the mentioned critical activities are positioned in the model in the form of sustainable value.
\end{abstract}

Keywords: sustainable value; tourism management; health resorts; spa tourism; sustainable business models; innovation business models; COVID-19

\section{Introduction}

Spa enterprises are organizations conducting tourism and therapeutic activities in places with confirmed medicinal properties of climate and access to deposits of natural resources used in treatment and prevention [1]. These enterprises conduct activities based on balneology and physical medicine therapy, complementing them with modern forms of biological regeneration, diet, sport, and recreation in areas rich in natural resources. This form of treatment and prevention combined with tourism is particularly popular in Central and Eastern Europe [2], where there are still many such areas, even more so in countries where curative therapy is integrated into the state healthcare system.

Unfortunately, the spread of the coronavirus, SARS-COV-2, and the consequent declaration of a pandemic by the World Health Organization (WHO) on 11 March 2020 halted all tourism activities, including those of spa companies. The reason for the global health crisis was the spread of the contagious and mutating SARS virus pathogen, first detected in Wuhan, Hubei Province, China in late 2019 [3]. The disease was reported to the WHO Country Office in China on 31 December 2019 [4]. Since then, the search for the eradication of the unknown virus and the mitigation of its health and economic impact has been ongoing.

In some countries, tourism-oriented spa treatment enterprises are part of the health system, making their involvement in pandemic response possible. Although they are generally not facilities that meet the requirements of general hospitals, their infrastructure can be helpful in certain situations as support to an overburdened healthcare system or as a humanitarian reservoir in disaster situations.

The aim of the article is to present a sustainable transformation of the business model of the tourism and medical enterprises, taking into account the determinants of the health 
crisis. The SusHT-CANVAS+ business model of spa enterprises proposed in the article takes into account elements of crisis management that are possible to implement in situations of epidemic threats.

\section{Literature Review}

The topic of business models has been presented in multiple versions in the literature [5]. The concept is used both in business [6], in non-profit organizations [7,8], and in politics [9]. It is not limited to the tool meaning of a scheme [10-13], as it is colloquially used both as a synonym for business strategy and a way of doing business, and even as an abstract term [14], showing the business model as a way of transforming resources into products and products into revenues. However, the problem of business modeling is a complex organizational process aimed at achieving multidimensional values. These values can target both satisfying consumer needs and value-added capture by the business. However, they can also serve to achieve social goals and even pursue global ideas.

\subsection{Business Models and Business Model of Spa Tourism Enterprise}

\subsubsection{Business Models}

The concept of a business model is relatively young, as the beginning of the evolution of business models was seen at the turn of the 20th and 21st centuries. However, R. Costa Climent and D.M. Haftor [15] point out that the term was first used decades ago by R. Bellman et al. [16] and Lang [17]. In order to explain what this business model is, selected definitions should be reviewed, which are quoted in the literature. One of the definitions is quoted by $\mathrm{H}$. Chesbrough and $\mathrm{R}$. Rosenbloom, who explain that a business model is a heuristic logic that connects technical potential with the realization of economic value. It provides a coherent structure that transforms technological features and capabilities (inputs) into economic products by interacting with customers and markets [18]. B. Wit [19], in turn, states that the essence of a business model is visual depiction of an organization's functioning logic, its elements or ventures in the form of appropriately named, interlinked elements of a template that-once populated with content-ensure logical understanding of the process of functioning, survival, and development of an organization. According to A. Osterwalder and Y. Pigneur [10], they define the business model as a conceptual tool containing a set of elements and their relations to set goals, allowing to expose the business logic of the company. Yet another approach is quoted by K. Obłój [20], who claims that a business model is a concept of a company's operation, which answers the questions regarding what the company will do, what its basic competences and resources are, and how they should be configured. Meanwhile, D. Teece [21] perceives them as a tool describing the design or architecture of creation supply or value-capturing mechanisms. According to him, the core of the business model is defining the way in which the enterprise captures value for customers, entices them to pay for this value, and calculates payables into profits.

S. Prendeville and N. Bocken [22] describe the business model as a conceptual tool, describing the activities that refer to business transactions between customers, partners, and suppliers, as well as the organization and their participation in the development and capturing of value. A different approach is presented by M. Johson et al. [23], describing it as comprising interrelated elements, including proposal of value, profit formula, key processes and resources that create and deliver the value. P. Keen and S. Quereshi [24] indicate a positive relationship between business model effectiveness and novelty and the value captured by the organization. They remind us that the fact of developing a business model does not determine the improvement of a company's effectiveness, but that only innovative solutions included in the model can contribute to obtaining the desired results.

M. Al.-Debei et al. [14] perceive the business model as an abstract textual or graphic representation of interrelated structures of a model architecture prepared by the organization, and of all the products and services that the organization has to offer that are essential to achieve its goal. 
A slightly broader definition of business models is provided by J. Brzóska [25]. Like M. Johson and others [23], he states that a business model is a system consisting of interrelated elements that interact with each other over time. Among the elements of the model, he includes the following: (1) the value offered to customers by the company; (2) the market segment to which the firm directs that value; (3) the range of product offerings; (4) pricing policies; (5) sources of revenue; (6) the necessary activities involved in making the value offered available; (7) the organizational capabilities that provide the basis for the business; (8) the skills and ventures that make it possible to sustain all aspects of competitive advantage; and (9) the sustainability of competitive advantage.

Similar division is seen in the CANVAS business model template by A. Osterwalder and Y. Pigneur [10] (Table 1). Their model also takes into account nine interconnected and interacting elements. These are customer segments, value proposals, distribution channels, customer relations, revenue streams, key resources, key activities, key partners and cost structures.

Table 1. The CANVAS business model.

\begin{tabular}{|c|c|c|c|c|c|}
\hline \multicolumn{6}{|c|}{ The CANVAS Business Model } \\
\hline Key Partners & Key Activities & \multicolumn{2}{|c|}{ Value Proposition } & $\begin{array}{l}\text { Relations with the } \\
\text { Customers }\end{array}$ & $\begin{array}{l}\text { Customer } \\
\text { Segments }\end{array}$ \\
\hline \multirow{3}{*}{$\begin{array}{c}\text { Network of } \\
\text { suppliers and } \\
\text { co-workers, whose } \\
\text { activity is crucial } \\
\text { for the effective } \\
\text { company } \\
\text { functioning }\end{array}$} & \multirow{3}{*}{$\begin{array}{l}\text { This element } \\
\text { usually contains a } \\
\text { list of key activities } \\
\text { that make it } \\
\text { possible to create } \\
\text { value for the } \\
\text { customer and } \\
\text { functioning of } \\
\text { particular } \\
\text { components }\end{array}$} & $\begin{array}{l}\text { It is a set of produ } \\
\text { generate value for } \\
\text { segment. It is the } \mathrm{r} \\
\text { prefer a particular } \\
\text { over those of cor } \\
\text { solving customers' } \\
\text { thei }\end{array}$ & $\begin{array}{l}\text { s and services that } \\
\text { particular customer } \\
\text { son why customers } \\
\text { ompany's offerings } \\
\text { etitors, as well as } \\
\text { oblems or satisfying } \\
\text { eeds. }\end{array}$ & \multirow{3}{*}{$\begin{array}{l}\text { It is an element } \\
\text { that describes the } \\
\text { characteristics of } \\
\text { the relationship } \\
\text { between a } \\
\text { company and } \\
\text { representatives of } \\
\text { a specific customer } \\
\text { segment }\end{array}$} & \multirow{3}{*}{$\begin{array}{l}\text { These are groups } \\
\text { of people and } \\
\text { organizations that } \\
\text { the enterprise tries } \\
\text { to reach and } \\
\text { service. }\end{array}$} \\
\hline & & Key Resources & Channels & & \\
\hline & & $\begin{array}{l}\text { It is a company's } \\
\text { most essential } \\
\text { resource that } \\
\text { influences its } \\
\text { performance }\end{array}$ & $\begin{array}{l}\text { An element that } \\
\text { indicates how a } \\
\text { company } \\
\text { communicates } \\
\text { with its various } \\
\text { customer segments } \\
\text { and how it offers } \\
\text { them its customer } \\
\text { value proposition. }\end{array}$ & & \\
\hline
\end{tabular}

\section{Cost Structure}

These are all expenses incurred in using a particular business model (financial outlays of key activities, resource costs, sources of major costs)

\section{Revenue Streams}

It is a wide element of the model encompassing such issues as the size of specific revenues streams in total revenues and payment methods

Sources: Own study based on CANVAS concept [10].

The literature proposes three phases for the transformation of the partnership-based business model [26-28]. The first phase is to get to know the existing business model. The diagnostic phase requires analyzing the existing model elements in order to maintain the good features of the current model and avoid its imperfections. The second phase is identifying the technological impact. It consists of two steps. In the first step, the impact of technological innovation is assessed, i.e., the identification of benefits and impacts of technology on the key elements of the business model. The second step is to identify gaps and ensure the continuity of partnership activities. The purpose of this activity is to fill the gap related to missing competences in the organization. In the third phase, the model is changed and improved. This happens in three steps. The first one concerns creating scenarios of cooperation activities with partners. Then, there is the formulation of new 
elements of the business model. The last stage is related to the assessment of the impact of the proposed changes on the company's operations.

A popular approach to transforming business models is the technique of systematizing knowledge and needs by means of a list of questions that define the assumptions of the new model. M. Morris et al. [29] propose six such questions: (1) how and (2) for whom do we create value, (3) what is the source of competences, (4) how does the enterprise compete, (5) how are its earnings and (6) what are the time ambitions, scope and size of the venture?

In turn, R. Amita and Ch. Zott [30-32] formulate a list of six elementary questions that can be an inspiration for constructing an innovative business model. These are the following questions: (1) what customer needs will the proposed business satisfy; (2) what actions should be used for this; (3) how can these activities be combined; (4) who will handle their implementation and on what terms; (5) how will the new value be created; (6) and how will the venture be profitable? You can see the similarity of the questions posed, which focus on the interrelationships and relationships between the model elements, and especially their relationship to the value proposition for the customer.

In the context of the transformation of the model in emergency situations discussed above, another question can be added to these questions-how can an enterprise help the society in situations of random threats?

\subsubsection{Spa Business Model}

In the scientific literature, there are also examples of models applied to tourismrelated businesses. M. Diaconu and A. Dutu [7] point out the evolution of innovative business models in the hotel industry. J. Souto [33] makes an analysis of innovation in the hotel industry. In turn, S. Grabowska [34] in her dissertation addresses the problem of business process modeling in the activities of tourism enterprises in competitive conditions. K. Herman and A.R. Szromek [35] develop a dedicated business model for heritage tourism enterprises, and also make attempts to apply the CANVAS scheme in relation to health tourism [36].

Researchers also address the topic of tourism business management with the application of popular business model schemes [37]. It is worth noting the business models for the identified sport tourism experiences of M. Perić et al. [38]. Many more works can be mentioned, but they only address the topic in the context of specific components of business models, not the entire model. They address, for example, customer relations $[39,40]$ or customer value $[41,42]$.

While the literature has promoted the adoption of more sustainable business models in tourism companies for many years, the COVID-19 pandemic has made this need more pronounced. The OECD [43] proposes that tourism companies shift to a more sustainable tourism paradigm in which companies have an important role to play. Their task is as follows:

- Application of environmentally friendly practices to transport, accommodation, food, and attractions;

- Better positioning of tourism activities, taking into account the positive impact on sustainable development;

- Use of technology to better manage the flow of visitors, avoiding overtourism and undertourism.

It is noteworthy that there is a need to develop strategic guidelines for the tourist destinations that find their way into the business models of tourism companies, while at the same time, making tourists aware of the right way to behave toward natural heritage. The tourism policy solutions recommended by the OECD aim at the following:

- Facilitating a paradigm shift in the perception of tourism success, taking into account the impact of tourism on environmental and socio-cultural elements.

- Adopting an integrated approach to tourism activities by coordinating the strategic objectives of the city, region, and national economy in integration with industry and the local community. 
- Integrating sustainable development practices into policy agendas at all levels of government by supporting the tourism economy in taking environmentally friendly actions and implementing programs to reduce emissions and climate change impacts.

- Implementing better methods of measuring the impact of tourism on tourist destinations, which are necessary in the management process.

- Developing sustainable business models in tourism enterprises.

It is worth emphasizing that the new paradigm of tourism "success" should not only measure the number of visitors and their spending (as before), but also take into account the level of positive impact of tourism on the indigenous community, local economy, and environment of the tourist destination.

While discussing the above guidelines, it is impossible to omit important solutions dedicated to tourism within the global system solutions. One of them is the set of criteria that the Global Sustainable Tourism Council (GSTC) developed for hotels, tour operators and tourist destinations [44]. The GSTC criteria allow an objective assessment of four groups of indicators (effective sustainable management, social and economic benefits to the local community, benefits to cultural heritage and benefits to the environment). However, this is only a statement of evaluation criteria, not a way to achieve sustainability goals.

In accordance with the recommendations of sustainable tourism business development formulated in the literature, researchers have made attempts to propose solutions for sustainable tourism. They are aggressively and dynamically implemented in health tourism since this activity is inextricably linked to direct interaction with the natural environment. Especially health tourism carried out in spa areas, which for centuries has played the role of natural enclaves with a confirmed impact on the human body, requires the implementation of business solutions protecting naturally valuable areas for future generations. However, the implementation of sustainable development principles in such places is often connected with reconciling the goals of many stakeholders in the area. A 2018 study [45] shows that the awareness of managers of tourism and medical enterprises on tourism business modeling is negligible. However, a positive aspect is the strong relationship of employees of these enterprises and their stakeholders with the environment. This provides a basis for the development of health tourism business in a sustainable way by providing appropriate management tools.

The business model of a health tourism enterprise developed for health tourism enterprises is presented in Table 2. The model presented there is based on the popular CANVAS scheme, so it is also possible to analyze the relationships between the components of the model [35,45]. As proved by the model developed by A.R. Szromek [45], the customer value proposition can also include solutions related to combating the effects of health crises.

It seems reasonable to deepen research in providing knowledge and effective business tools to managers of tourism enterprises. Awareness of their existence and ability to apply them is the beginning of beneficial changes. It also concerns an attempt to change the paradigm of success in tourism and to include its environmental needs. 
Table 2. The business model of spa tourism enterprise.

\begin{tabular}{|c|c|c|c|c|c|}
\hline Key Partners & Key Activities & \multicolumn{2}{|c|}{ Value Proposition } & $\begin{array}{l}\text { Relations with the } \\
\text { Customers }\end{array}$ & Customer Segments \\
\hline $\begin{array}{l}\text { - } \begin{array}{l}\text { Social and health } \\
\text { state insurers, }\end{array} \\
\text { tour operators } \\
\text { - } \text { Outsourcing of } \\
\text { catering, spa } \\
\text { treatments } \\
\text { - } \text { Coopetition } \\
\text { between } \\
\text { competitors } \\
-\quad \text { Suppliers } \\
-\quad \text { Spa commune } \\
\text { and central } \\
\text { administration } \\
\text { government }\end{array}$ & $\begin{array}{ll}\text { - } & \text { Spa treatment } \\
\text { - } & \text { Accommodation } \\
\text { - } & \text { Catering services } \\
\text { - } & \text { Spa and wellness, } \\
& \text { sport services } \\
- & \text { Tourist services } \\
- & \text { Additional } \\
& \text { services } \\
- & \text { Transportation } \\
& \text { services } \\
- & \text { Post-COVID } \\
& \text { therapy }\end{array}$ & 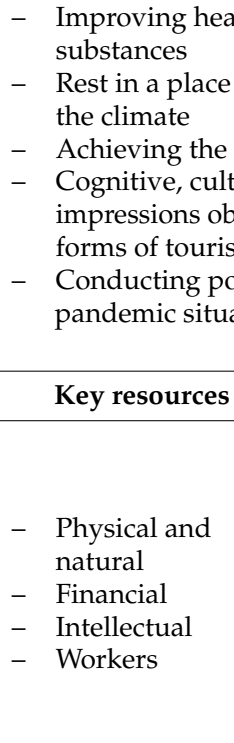 & \begin{tabular}{ll} 
& \multicolumn{1}{c}{ Channels } \\
- & Communication \\
with the client \\
- Outpatient clinics \\
and clinics \\
- Media, leaflets, \\
folders \\
- Internet, websites, \\
- social media \\
Travel agencies
\end{tabular} & 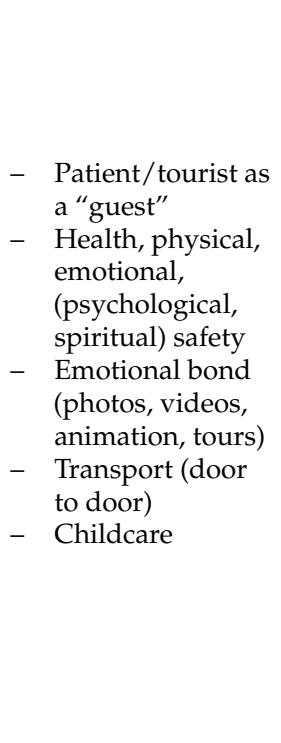 & $\begin{array}{ll}- & \text { Patients referred } \\
\text { for treatment } \\
-\quad \text { Patients without } \\
\text { referral (private) } \\
-\quad \text { Tourists } \\
\text { (weekend and } \\
\text { long-term) } \\
-\quad \text { Foreign tourists }\end{array}$ \\
\hline
\end{tabular}

\subsection{From Sustainable Business Models to Open Innovation}

\subsubsection{Sustainable Development Concept}

The development of the media in the 1960s significantly increased the availability and speed of news coverage. A consequence of the development of the media was also the dissemination of information about environmental changes, environmental disasters, and related threats [46]. Awareness of environmental degradation stimulated social responsibility and activity in international forums, with numerous environmental conferences. Probably the landmark event was the Earth Summit within the framework of the Second UN Conference Environment and Development (3-14 June 1992) in Rio de Janeiro. It adopted 27 general principles and obligations on development and the environment (Rio Declaration [47]) and a global action program for sustainable development of the world (Agenda 21) [48].

The concept of sustainable development is in constant evolution. The original assumptions aimed mainly at pro-environmental actions but over the decades, have been expanded to include other dimensions. J. Mensah [49] states that the contemporary concept of sustainable development is essentially based on three integrated dimensions, i.e., environment, economy and society, the essence of which are the mutual relations, complementarity and compromise between these pillars as well as social responsibility in terms of human behavior and actions at the international, national, community and individual levels. It is a ubiquitous development paradigm and a useful slogan in scientific campaigns and conferences and activist activities [50].

The need for the evolution of sustainable development is due to the problem of increasing population with limited natural resources. The lack of impact on the world population makes one think about the judicious use of available resources. The goal of 
these actions is to meet the needs of the current generation without limiting the ability of future generations to meet their needs. Hák et al. [51] note that the realization of this goal is contingent on ensuring a balance between economic growth, environmental integrity, and social well-being.

The environmental dimension of sustainable development concerns ecosystem integrity and environmental capacity [52]. J. Mensah [49], quoting M. Diesendorf [53] and B.A. Evers [54], recalls that according to the accepted idea of sustainable development, the rate of human use and consumption of natural resources should not be higher than the rate of their renewal, and the production of waste should be faster than its disposal. Due to the fact that these problems are generally still beyond modern human capabilities, the concept of sustainable development is still only an unattainable idea.

The economic dimension of sustainable development is related to appropriate management of resources, taking into account their limitation. Initially, it was believed that the progress of civilization would make it possible to renew them, which would then give them the feature of a lack of any limits; therefore, the loss of resources was accepted. However, the realization of the fact that the constant limitation of resources progresses faster than the development of the ability to renew them has led to a change of position. The intermediary economic evaluation of environmental damage is also being carried out [55].

References emphasize [56] that sustainable development in the social dimension is about promoting the development of people, communities, and cultures for a standard of living that enables the enjoyment of adequate health care, education, peace and stability around the world, as well as gender equality. Therefore, this dimension also seems to be extremely difficult to achieve.

All three dimensions of sustainable development are mutually integrated, which means that achieving the goals of one dimension supports the goals of the others. However, the issue is very complex, as its success is determined by many other economic categories, such as complementarity or synergies or the ability to compromise and accept tensions [49].

\subsubsection{Sustainable Business Models}

One of the important solutions to the problem of sustainability in business are sustainable business models and their subsequent transformations. The idea of business models based on the concept of sustainability in the scientific literature was initiated in 2002 [5]. M. Geissdoerfer et al. [57] define a sustainable business model (SBM) as a simplified representation of the elements, the interrelation between these elements, and the interactions with its stakeholders that an organizational unit uses to create, deliver, capture, and exchange sustainable value for, and in collaboration with, a broad range of stakeholders. However, the term sustainable business model itself was coined much later. J. Feng et al. [58] claim that the term was first proposed by F. Boons and F. Lüdeke-Freund in 2013 [59]. Since its inception, it has attracted considerable interest from academics and practitioners who argue that it may eventually displace the traditional concept of business models [60]

A sustainable business model is a model that has a long-term perspective and is based on proactively managing multiple stakeholders and creating monetary and non-monetary value for a wide range of stakeholders [61]. SBM is also considered a source of competitive advantage [62].

However, the literature review proves that different concepts of creating sustainable business models are used in practice. One example is the generic business model concept, based on the publications of A. Osterwalder [63] and L. Doganova and M. EyquemRenault [64], which involves the formulation of four elements (value proposition, supply chain, customer interface, financial model) [65]. The first issue is to extend the value proposition in the business model to include measurable environmental value and/or social value in concert with economic value. The second issue is to extend co-responsibility for the environment, but not only for our own actions but also for the actions of our stakeholders. The third is to work with consumers to motivate them to take responsibility 
for their own consumption. The fourth element is the division of costs and benefits from the introduction of the previous three elements.

A similar approach is proposed by S. Nosratabadi et al. [5], who list four elements of SBM design, namely (1) designing a sustainable value proposition, (2) designing sustainable value creation for all stakeholders, (3) designing sustainable value delivering and (4) generating sustainable partnership networks for creating and delivering sustainable value, which can meet the social, environmental, and economic benefits at the same time.

M. Geissdoerfer et al. [61] note that SBMs are modifications of the conventional concept of business models, which are generally created in two ways. The first is to implement into the model the principles and objectives leading to sustainable development, while the second is to integrate sustainable development with the value proposition and the value capture mechanism.

This approach is supported by some definitions of sustainability. W. Stubbs and C. Cocklin [65] note that implementation of the sustainability concept shapes the driving force of the firm and its decision making, not so much in the form of supplementing the model, but rather in its transformation. However, N. Abdelkafi, K. Tauscher [66] capture SBM precisely by integrating sustainable development with the company's value proposition and value creation logic.

On the other hand, F. Boons and F. Lüdeke-Freund [59] mention four elements that distinguish SBM. The first is measurable environmental or social value combined with economic value. The second is collaboration with responsible suppliers, and this responsibility applies to the company's own actions as well as to its stakeholders. The third element also relates to the responsibility, but this time of customers for their own consumption and stakeholders; the role of the company in this case is to motivate the customer toward responsibility. The fourth element is the financial model, which takes into account the distribution of costs and benefits among the actors of the business model, but also the environmental and social impact of the company.

However, even these models can take very different forms. They can be observed, among others, in publications by T.S. Thorisdottir and L. Johannsdottir [67], A. Jabłoński [68], or C. Giannoni et al. [69]. I. Lemus-Aguilar et al. [70], through analyzing the proposals of N.M.P. Bocken et al. [71] and P. Rital et al. [72], propose to divide SBM into nine archetypes (Table 3).

Table 3. Sustainable business model types.

\begin{tabular}{cll}
\hline Focus & \multicolumn{1}{c}{ Archetypes } \\
\hline & (1) & Maximize material and energy efficiency \\
Environment & (2) & Closing resource loops \\
& (3) & Substitute with renewables and natural processes
\end{tabular}

(4) Deliver functionality rather than ownership

Social (5) Adopt a stewardship role
(6) Encourage sufficiency

(7) Repurpose for society/environment

Economic

(8) Develop sustainable scale-up solutions

(9) Inclusive value creation

Source: Based on [70].

On the other hand, M. Geissdoerfer [61] mentions sustainable business models among the types of models, and among their examples he includes the following: (1) circular business models, which close, slow down, intensify, dematerialize, or narrow resource loops; (2) social enterprises, which aim to make a social impact by generating business 
profits or reinvesting them; (3) bottom of the pyramid solutions, which are models aimed at influencing customers at the bottom of the income pyramid; and (4) product-service systems, which integrate products and services into customer offerings. The most frequently discussed referenced example is the circular business model, whose emergence is related to the use of sustainable models in the circular economy (Figure 1).

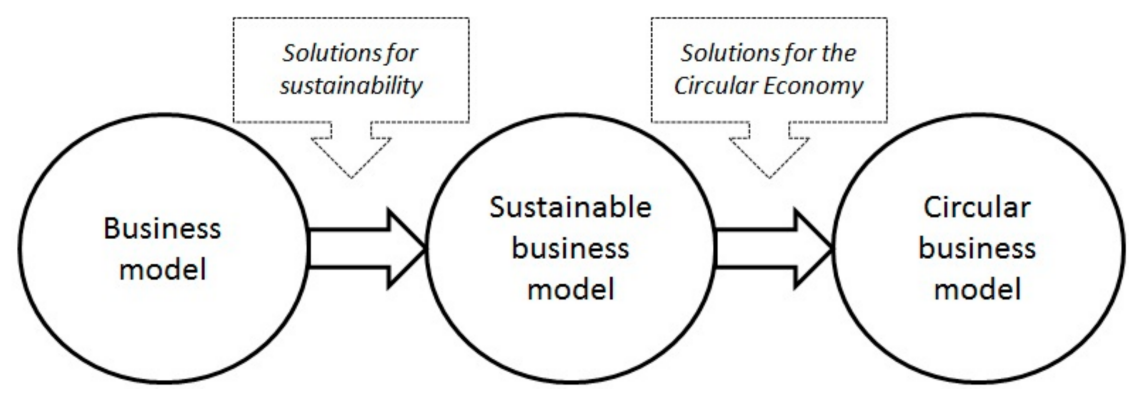

Figure 1. A holistic view of sustainable value integrating economic, environmental, and social value forms. Source: Own study based on [61].

A. Urbinati et al. [73] reference the opinion of W.R. Stahel [74] that the circular economy (CE) is an economic paradigm that is unlike the most common and traditional linear "take, make, dispose" model. Its goal is to minimize the use of raw materials, extend the life of the product as much as possible to get the maximum value from it, and when it reaches the end of its life, reuse spare parts and components to reduce the overall demand for raw materials. Two loops of reuse, repair, remanufacturing and recycling and two junctions are used here-product-life extension versus new goods and virgin materials versus recycling materials. A similar opinion is quoted by D. Chiaroni, A. Urbinati [75]. In turn, A. Zucchella, P. Previtali [76] focus on two issues of circular business models. The first one is the focal actor and the second one is the circular ecosystem (suppliers, customers, research centers, and public authorities) in which the actor or stakeholder plays its role. There is also no lack of references to the role of the customer in these models [77].

References repeatedly prove that the mutual relationship between sustainable business models and innovative business models finds its special place in the ecological plane. S. Evans et al. [78] place additional requirements on sustainable business models (SBM), including innovativeness, linking them to innovative business models (BMI). In contrast, the already cited team of N.M.P. Bocken et al. [71] find that BMI can help companies achieve triple bottom line results by meeting social, environmental, and financial goals. A form of implementation of business intentions combining BMI and SBM models can undoubtedly be circular economy.

The literature on the subject covers the practical usefulness of business models in creating innovative solutions, but also in the direct exchange of innovation and knowledge. One of the significant developments of this concept (and maybe even philosophy) is the perspective of J.J. Yun [79], who presents the new combination business model developing circle. The four business models of J.J. Yun, dedicated to customers (consumers), entrepreneurs, social entrepreneurs and engineers, are examples of how open innovation can be the source of creative business models.

The evolution of innovative business models toward open innovation is widely discussed in the literature $[80,81]$. However, each of the publications broadens the scope of knowledge in this direction, and thus enables the creation of new solutions and products within the concept of open innovation [82]. An example may be the publication of R. Amit and C. Zott [31], who remind that innovations in a business model can occur in many ways: (1) by adding innovative activities, (2) by combining activities in an innovative way, or (3) by changing one or more parties that perform any of the activities. However, they point out that the introduced changes do not have to be radical to bring benefits. Paradoxically, even small changes can significantly affect the industry. 
H.W. Chesbrough $[11,18,83]$ even argues that the organization must provide managers with resources and take the risk of experimenting with its own business models. It also provides the so-called Business Model Framework (BMF), whose task is, inter alia, assessment of the innovation potential of a new business model.

J.J. Yun and X. Zhao [84] discuss a thinking experiment based on the rectangular compass concept model. As a result, they develop 17 patents of business models. Thanks to this, we know that open innovation (based on a new combination of technology and market) is the driving force behind the innovation dynamics of a sustainable business model.

An interesting example of the use of open innovation is the publication of J.J. Yun et al. [85], who indicate the significant benefits of using open innovation for environmental protection. They discuss these benefits in the context of the car-sharing industry. Based on a case study, they developed a causal loop model for the car sharing industry. They note that open innovation activities have a positive impact in accelerating the underlying reinforcement loops between system, income and accountability.

\subsubsection{Sustainability Value Proposition}

The connecting element of all business model concepts is the value proposition. Some definitions of business models explicitly point to value proposition as the core of the model. They are defined as simplified representations of the value proposition, value creation and delivery, and value capture elements and interactions between these elements [61].

While, initially, the value in a business model was limited to the customer value proposition and the value captured by the business (most often in the form of profit), it is already difficult to imagine a value proposition structure today that does not include community and environmental values [86]. It seems that the dynamism of the development of this "third" group of values should progress commensurate with scientific reports on the deteriorating state of the environment [87]. R. Hiteva and T.J. Foxon [88] even state that the higher up business models are in the innovation ladder, the more abstract and limited articulation of social and environmental values. S. Schaltegger [89] states that customer value and social value in a sustainable business model require the integration of social, environmental, and business activities.

However, there has been a noticeable evolution in values in business models. Some concepts assume treating social and environmental values as a separate class of values generated by the business (in the sense of positive impact on the environment by environmental activities), while others identify these values as one of the consequences of value capture by the business (in the sense of negative impact of the business on the environment).

The division of key values in the business model into three values (value for the customer, value captured by the enterprise and value for society) is applied by A.R. Szromek and M. Naramski [90]. A. Joyce and R. Paquin [91], using the CANVAS model, implement even two additional levels: environmental and social. It is, at the same time, an important concentration of attention on the elements of social influence. On the other hand, W. Stubbs and C. Cocklin [65] go a step further and propose to treat society and nature as stakeholders of the enterprise. Y. Jang et al. rely on the value generated for the customer and captured by the company [92]. On the other hand, R.W. Butler and A.R. Szromek [93] separate social values from other value groups and formulate a simple relationship between them. They indicate that the customer value proposition has a significant impact on the amount of value captured by the company. In turn, the value captured also affects the degree to which the assumed economic goals of the enterprise are achieved, and thus the commitment to social (including pro-environmental) goals. This means that the achievement of social and environmental goals is determined directly by the amount of value captured and indirectly by the attractiveness of the value proposition to the customer.

If value is not captured by the company, one or more reasons may be the cause. M. Yang et al. [94] list four such situations, i.e., value surplus (exists, not required), value absence (required, does not exist), value missed (exists, required, not exploited) and value destroyed (value with negative consequences). It is this last situation that points to the 
negative impact on the environment, among others, as a consequence of value capture by the company.

Assuming the presence of (described by R.W. Butler and A.R. Szromek [93]) simple interdependencies between individual values in the business model, the correct diagnosis of the situation and the manager's reaction will influence not only the improvement of the company's situation, but also the realization of the value proposition for society and the environment. However, it is necessary to also consider the situation in which the relations between values have a different, and probably more complex and multi-directional flow. N.M.P. Bocken et al. even argue that for sustainable business models, it is necessary to take a holistic view of the value proposition, which includes benefits and costs for other stakeholders, especially for society and the environment [71]. It is useful to refer to holistic value integration for this purpose.

In the second decade of the 21st century, the literature recognizes an attempt to formulate sustainable value (Sv) [78]. They are defined as the values resulting from the integration of economic, environmental, and social value forms (Figure 2). S. Evans et al. explain that the essence of sustainable business models is to take into account in the company's activities precisely the three mentioned areas of its impact, while responding to the needs of stakeholders and equalizing the interests of all stakeholder groups.

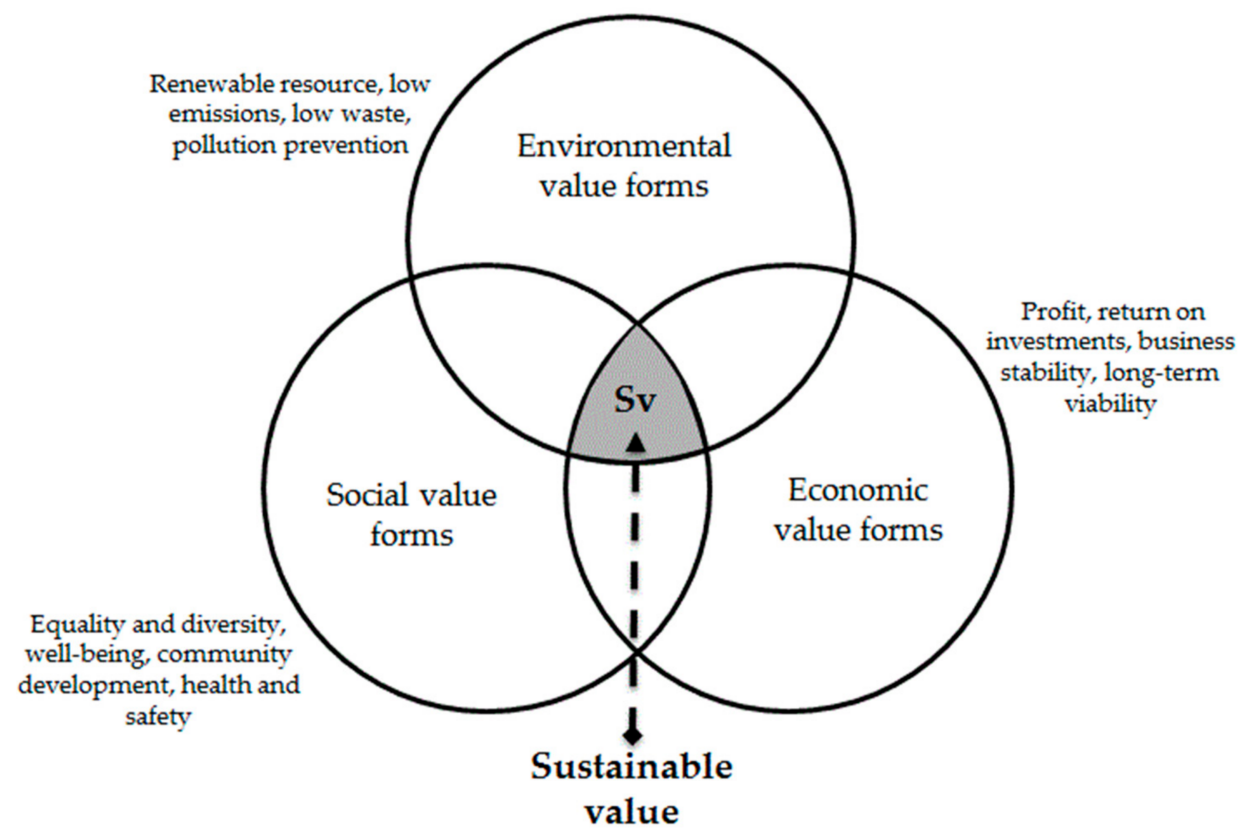

Figure 2. A holistic view of sustainable value integrating economic, environmental, and social value forms. Source: Own study based on [78].

The idea of sustainable value resembles J. Elkington's concept known as the triple bottom line (TBL or 3BL) [95]. It is a conception in the form of an accounting framework, evaluating business activities from a broad perspective, precisely taking into account the three areas of impact: social, environmental/ecological, and financial. This approach has become extremely popular in the literature, and is often taken up [96-98] and even developed by researchers, e.g., by taking into account the time dimension, orienting business activities with future generations in mind [99]. However, it is worth remembering that this concept in its assumption shifts the responsibility from shareholders to stakeholders, and then the company becomes a vehicle for conducting business oriented toward the welfare of employees, customers, suppliers, the local community, and the environment. Thus, the benefits of shareholders and stakeholders become interdependent or even unbalanced in favor of the stakeholders.

At the same time, this is another part in common with sustainable business models. N.M.P. Bocken [71] note that the goal of sustainable business models is to seek to go 
beyond delivering economic value and include consideration of other forms of value for stakeholders. There are six stakeholder types: customers, investors and shareholders, employees, suppliers and partners, the environment, and society.

T. Ying et al. [100] note that tourism researchers should consider taking on new topics for future research programs, setting them in the context of consumer behavior and marketing and crisis management to better address viral threats and other public health concerns.

The Value Mapping Tool [71] proves extremely useful for creating value in a sustainability-focused enterprise. It facilitates value creation through mutual relationships of value proposition, value destroyed, value missed and opportunities for new value creation, in relation to stakeholders. Equally valuable is the approach based on life-cycle thinking (value captured or uncaptured into beginning of life (BOL), middle of life (MOL), and end of life (EOL)) [101], multiple value forms in the Sustainable Value Analysis Tool (SVAT) [102], three-dimensions of sustainability and their intersections [103], and others.

\section{Materials and Methods}

Health resorts play an exceptionally important role in overcoming the health crisis caused by the SARS-CoV-2 virus. In Poland, they were a safeguard for the medical infrastructure in case of overcrowding in specialized hospitals. The potential of Polish health spas in terms of spa treatment includes 241 sanatorium facilities and spa hospitals, which hosted 838,500 guests in 2018.

The analysis of changes in the business models of tourism and medical treatment companies operating in spa areas was carried out on the basis of our own research conducted in 2021 by the method of in-depth interviews conducted among managers of these companies acting as experts. The research was conducted one year after the announcement of the SARS-CoV-2 coronavirus outbreak, i.e., after 12 months of operation of spa companies in specific sanitary conditions dictated by business restrictions and lockdowns.

The group of experts consisted of managers from 19 of the largest tourism and medical spa enterprises, with 115 spa facilities. Thus, the managers participating in the study represent $48 \%$ of the potential of all sanatorium facilities in Poland [104].

The selection of experts was based on the following criteria:

1. The expert could only come from a spa company, placed by the state administration on the list of spa treatment facilities, conducting treatment and tourism activities in the spa [105].

2. The expert could only be the highest-level manager (president) or his/her designee (lower-level manager, division director or legal advisor).

Experts could comment on specific components of the business models. To conduct the research, a research questionnaire was developed and divided into several parts. The first three parts were informative, and only the fourth part was a core set of opinion questions.

The first part of the questionnaire asked experts about changes in their business due to the outbreak of the coronavirus pandemic. Among other things, they were asked which types of spa activities had been reduced and which had expanded.

The next part of the questionnaire dealt with the topic that was the core of the experts' opinion. It included questions about changes in business models caused by the coronavirus pandemic. The experts were able to indicate those areas of business activity in which they perceived significant differences, in relation to the state before the pandemic. This part of the research was conducted based on the division of business model elements according to the CANVAS concept of A. Osterwalder and Y. Pigneur [10]. This issue was also extremely difficult due to the fact that the knowledge of business models in spa establishments is fragmentary and most often intuitive, i.e., disordered in relation to any concept of business models [35]. The research questionnaire contained other thematic issues not related to the business model, so they were included in other publications of the author.

The expert opinion obtained by this method is, at the same time, complementary to the research conducted by the author in 2018-2020 on business models of spa enterprises [36,45]. 
The progress of global changes aimed at implementing the principles of sustainable development in the economy of countries as well as the coronavirus pandemic, which intensified the ongoing changes, forced the need to supplement the ongoing research. The issues addressed in this article complement the existing research on changes in health tourism business models.

\section{Results of Own Research in Enterprises of Health Tourism and Treatment}

The COVID-19 pandemic has halted or at least reduced the activities of many industries, including the tourism industry. However, a certain part of this industry has changed its business profile to support the emergency response. Tourism and medical treatment enterprises, established for the realization of health and preventive goals during tourist stays in spas through balneological therapy and physical medicine conducted there, undertook various activities during this period. As they are part of the healthcare system, they can play an important role in emergency situations, both when it comes to population evacuation and treatment, or epidemiological activities.

During the first year of the pandemic, from 20 March 2020 to 20 March 2021, Polish health resort companies acted as COVID-19 treatment hospitals, isolation facilities for people in quarantine, post-COVID rehabilitation centers, COVID-19 vaccination points, etc. During periods of reduced incidence, some of them conducted spa treatment, outpatient treatment (spa treatment) and health tourism activities.

The survey of the 19 enterprises in question (covering 115 establishments) in March 2021 established that during the year of the pandemic in the surveyed entities, general spa therapy was carried out slightly more often than in every other enterprise (55.6\%) for 177 days per year on average, although this was done in a manner limited by sanitary considerations.

The other activity most frequently indicated by managers was post-COVID therapy, i.e., rehabilitation of post-COVID-19 individuals whose disease left them with ailments that did not require treatment in a specialized hospital. This type of therapy was reported by every other facility ( $50 \%)$. It lasted an average of 153 days per year.

Nearly one in three facilities $(27.8 \%)$ established isolation rooms for quarantine patients who were confirmed to have the SARS-CoV-2 or COVID-19 virus but did not require hospital treatment. This function was performed by the surveyed facilities for an average of 107 days per year.

In contrast, the role of the COVID-19 vaccination point was performed by almost every second facility ( $44.4 \%$ ) for an average of 60 days. However, this result is subject to a significant limitation, as it should be added that vaccination took place throughout the period of availability of the vaccine, as it was not available until January 2021 (Table 4).

Table 4. Structure of functions performed by spa enterprises.

\begin{tabular}{ccc}
\hline $\begin{array}{c}\text { Actions Implemented by Spa Businesses } \\
\text { during the COVID-19 Pandemic }\end{array}$ & $\begin{array}{c}\text { Percentage of } \\
\text { Establishments }\end{array}$ & Time (Days) \\
\hline Spa therapy (stationary and outpatient) & $55.6 \%$ & 177 \\
Post-COVID therapy & $50.0 \%$ & 153 \\
Isolation section for people in quarantine & $27.8 \%$ & 107 \\
COVID vaccinations & $44.4 \%$ & 60 \\
Tourist services & $11.1 \%$ & 270 \\
Renting rooms to medical services & $11.1 \%$ & 90 \\
COVID-19 patient therapy & $16.7 \%$ & 60 \\
Specialist therapy & $5.6 \%$ & 120 \\
\hline Source: Based on own study.
\end{tabular}

Source: Based on own study.

The longest-running activity during this time was tourist service, which was as high as 270 days. However, this involved very few visitors and occurred in only two establishments. The remaining businesses complied with the restrictions and did not attempt offering tourist service at all. 
The function of treating COVID-19 patients was very rarely assigned to spa establishments $(11.1 \%)$ and usually lasted for about 60 days. The treatment of COVID-19 patients was carried out in infectious diseases hospitals and in specially designated wards of some city and provincial hospitals. During periods of increased incidence, supplementary hospitals were set up to treat people who were ill with COVID-19 but did not require intensive care. These were created in various public places, such as stadiums, market halls, performance halls, and, in a few cases, tourist facilities.

Thus, it should be noted that the change in the dominant profile of tourism and treatment enterprises operating in health resorts consequently led to changes in the components of their business models. The experts, who were also the facility managers, most often indicated changes in the value proposition ( $83.3 \%$ ) and in key activities $(83.3 \%)$, but there were also changes in revenue streams $(83.3 \%)$ and costs $(55.5 \%)$, and, in a few cases, in key partners $(16.7 \%)$.

The biggest changes were seen in the value proposition. It is worth noting, however, that managers did not reduce the customer value proposition, as they maintained their willingness to perform their existing functions during the pandemic, and sometimes performed them to a limited extent. Some reductions occurred in captured values, as the lack of profit opportunities, while considered temporary, was a significant burden for these companies. The greatest changes occurred in the social value proposition, as the implementation of pandemic-control activities was indicated by managers as a value to society.

Among the indicated values for society, the aspect of positive impact on the local economy was the most popular (66.7\%). This was about the benefits to the local community provided by the activities carried out by the spa company. This was especially the reduction in the unemployment rate and the increase in income for the community. Undoubtedly, maintaining full-time employment at these facilities was an important aspect-no change in this regard was shown by half of the facilities (52.9\%), and another $23.5 \%$ limited themselves to not renewing employment with employees whose fixed-term contracts had terminated.

An equally frequently formulated element of the value proposition to society was to serve as a back-up treatment base in national or global security emergencies $(66.7 \%)$. It is important to mention, however, that the study also found few instances of protests by residents of these municipalities against the implementation of anti-COVID functions due to concerns about the spread of infectious disease to non-tourist neighborhoods.

Other elements of the community value proposition were the effects of implementing renewable energy systems (e.g., solar panels, heat pumps, photovoltaic panels) (22.2\%). One site emphasized the role of environmental education of visitors, aiming to reduce water and energy consumption, as well as pollution and waste in the community (5.6\%).

Changes were also noted in key activities. The pandemic situation prompted some managers to include post-COVID therapy (61.1\%), implementing a vaccination program for COVID-19 (38.8\%), or offering space in an isolation facility $(16.7 \%)$, and providing treatment for COVID-19 patients (16.7\%) as key activities.

Due to the lack of income from tourism activities, many facilities experienced changes in revenue and cost streams. A total of $77.8 \%$ of the facilities analyzed received nonreimbursable financial support from the state through the Anti-Crisis Shield, and $11.1 \%$ of the facilities received special purpose funding to treat COVID-19 patients with ongoing therapies. On the cost side, half of the establishments (55.6\%) reported a reduction in costs due to the inability to provide tourism and treatment services. Individual managers also noted non-financial solutions they used. These were deferred payment, and income from production activities carried out together with tourism and medical activities.

Few managers, due to the crisis, supplemented the group of key partners with state administration bodies, including the provincial marshal, with whom they cooperated during that period $(16.6 \%)$. One manager admitted that the supply chain at his plant was disrupted, not because of reduced demand, but due to the closure or suspension of stakeholder plants. 


\section{Discussion}

The obtained research results prove that tourism enterprises can not only have a significant impact on the implementation of tourism activities, but also can play an important rescue role. The example of Polish medical tourism establishments fulfilling additional social roles during epidemic threats reveals that maintaining the link between the tourism business and the public health system is an extremely valuable organizational solution. It should be noted that these businesses are not owned by the state, but are private enterprises and, as such, make their own business decisions. However, their participation in the health system through the implementation of health contracts concluded with the state health insurer imposes on them a number of requirements, including those to be met by healthcare facilities. This fact makes them both a part of the tourism sector and the healthcare sector in which the main contractor is the state insurer (National Health Fund).

In the period of the COVID-19 pandemic, the state's activities directed at undertaking emergency actions of the national or global range are conducted through the healthcare system. Epidemiological threats are reduced, first of all, by the established hospital departments permanently dealing with infectious diseases, functioning on different levels of health care. Next, actions are taken to increase emergency potential, e.g., by limiting medical activities in other wards to life-saving treatment only, or by enlarging the existing infectious disease units. Further organizational decisions include adapting non-medical infrastructures for temporary medical units with a differentiated role in the chain of emergency or protective actions taken. These may be market halls or office buildings converted into field hospitals, or arrival and departure halls at airports, which in extreme cases may serve as a sanitary buffer in the isolation of quarantined individuals.

It should be noted, however, that the above-mentioned facilities are much more difficult to adapt to healing conditions than hotel facilities with accommodation. Hence, the extremely valuable humanitarian reservoirs are the tourist and therapeutic facilities operating in health resorts. The conducted research proves that these facilities fulfilled their rescue and prevention roles, especially in the field of post-COVID therapy, which was carried out by every second, surveyed company. Another important role performed by almost every third spa facility was that of an isolation facility for people in quarantine. In contrast, the role of vaccine distributor was very popular later on. These three tasks most commonly undertaken by spa facilities enabled them to relieve the burden of medical units, directly saving the lives of COVID-19 patients with complications.

The solution of using such enterprises to counteract the effects of health and especially epidemiological disasters has another important advantage. It should be noted that in accordance with the regulations in force in Poland, sanatorium centers are located in a strictly defined zone of the health resort destination, which is far away from settlements inhabited by the local population. This provides an opportunity to isolate people at risk of illness from large concentrations of residents.

Taking into account the opinion of some researchers who say that such significant events are not insignificant for the future functioning of tourism and, at the same time, give rise to the necessity of implementing pro-developmental changes in tourism $[106,107]$, it is worth considering the introduction of additional functions and tasks of tourism and treatment enterprises on a permanent basis. Actions taken by these companies during the period of a pandemic seem to be almost natural in the face of the situation of stopping tourist traffic and the necessity of saving human life and health.

The proposal of adopting applied preventive solutions as key actions of spa enterprises, or at least maintaining readiness for preventive actions, seems to be even more justified in light of the confirmed historical observations [108] that the frequency of appearance of new viruses and their mutations has increased in the 21st century. Since they will appear more and more frequently, solutions, this time adopted only on an ad hoc basis, may soon become part of everyday life in a few years. However, the adoption of additional functions will significantly affect the structure of the business model. Therefore, it is worth undertaking a discussion on changes in business models in this area. In developing the 
proposal for the transformation of the business model, the methodology of introducing changes to the proposed literature, discussed in the literature review, was used [26-28].

Undoubtedly, a fundamental component of any business model is the value proposition [78]. It is the values that give the business meaning. Therefore, it is obvious to include additional prevention and protection activities in the value proposition of the business model. However, supporting the healthcare system in a health disaster involves a complete change in the business profile, and this incurs huge financial costs and dramatically changes the other components of the model. There even seems to be a more complicated process of change in shifting from a tourism to emergency business than occurs in other sectors of the economy.

During the pandemic, many windshield-washer-fluid companies changed their business profile to disinfectant fluid production. Some passenger transportation companies abandoned the continuation of cross-country cruises in favor of cruises bringing tourists into the country. Some universities have refocused their intellectual resources to fight the virus, directing research toward the invention of a vaccine or the development of technology to produce respirators or gates (curtains) to disinfect protective suits, which reduce the risk of infection, when medical teams remove them [109]. Similarly, the change in the business profile in health facilities required the transformation of almost all elements of the business model; hence, the previously developed models [36], when the pandemic was announced, proved to be insufficient.

Therefore, it is necessary to propose a transformation of the business model of spa enterprises, taking into account the just-mentioned prevention and rescue activities, such as post-COVID therapy, isolation, and antiviral vaccination. Modifying the previously developed model $[36,45]$, the structure of the CANVAS model, which is presented in Section 2.1.2, special consideration should be given to changes not only in the key activities, taking into account the above functions, but also in the key partners, which should undoubtedly include government entities at various levels and other contractors also undertaking compatible prevention activities. Additionally, key resources should include an adequate level of viral protection materials in the form of viral tests, vaccines, disinfectants, and protective suits, in case an epidemic threat is detected among tourists and a rapid preventive response is needed. Additional items need to be included in the cost structure, as preparedness alone will consume additional costs, not to mention if intensive care is required.

So far, additional items have been listed in the model. It is worth noting, however, that in the case of a tourist stoppage, the elements on the right side of the model lose their significance. It is impossible to build relations with clients in the period of a health threat, to create distribution channels or analyze market segments. As the model is reduced by the above-mentioned components, the revenue structure also changes. The loss of income from servicing tourist traffic has to be covered from other sources. Receiving state subsidies for prevention and rescue tasks should allow the company to at least cover the losses generated during the outage period.

In the case of the value proposition, so far, it has only been noted that it should take into account the additional functions of spa facilities, but it seems that the problem is more complex. Reference should be made here to the breakdown of values present in business models and a holistic view of sustainable values, integrating economic, environmental, and social value forms by S. Evans et al. [78].

The identification of value propositions in the business models of tourism and medical enterprises should begin with a discussion of the types of values to be considered. The literature review mentions that one sees both a division of value into customer value and value captured by the enterprise [79], and a tri-division, emphasizing the importance of social value, which takes into account the values generated by the enterprise toward the local community as well as the environment [93]. However, the concept of sustainable [78] value was also cited, which takes into account the value created through the integration of economic, environmental, and social value forms. It is the integration of these three 
forms of values that makes it possible to define sustainable value in a tourism enterprise (Figure 3).

- improvement of health with natural therapeutic raw materials -recreation in a place with a healing climate -achieving the effect of the treatment (relaxation, beauty, improved beauty, weight loss, improvement of fitness and sports results)

- cognitive, cultural, and religious impressions obtained through various forms of tourism

- health education and health security during the stay

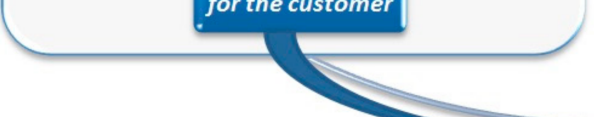

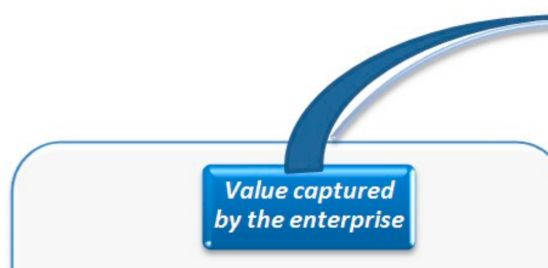

- profits from the sale of products and services

- contracts with the state insurer

-building the brand and popularity of the resort

-increasing tourist capacity

-increasing the company's value

-positive relations with internal and

external

-satisfaction with the implementation of

the social mission

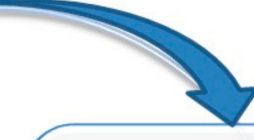

- equal opportunities for employment and promotion of the inhabitants of the local community

-implementation of environmental protection programs (low exhaust emissions, reduction of water consumption, reduction of postproduction waste, installations of renewable energy sources) - promoting local culture and heritage -emergency medical and housing reserve in the event of health, environmental, terrorist disasters

Figure 3. A holistic view of sustainable value integrating economic, environmental, and social. Source: Own study.

Sustainable value generated by a spa enterprise should take into account the actions and principles that realize the interests of the enterprise's stakeholders, especially the environment and residents of the tourist destination, i.e., the local community. Nowadays, actions targeting the protection of the natural environment are an obvious requirement in the realization of business plans. There is no need for the company to adapt its own requirements, as they are usually regulated by the state. However, if it happens, it is often an element of competitive advantage of the company, which is trying to raise quality standards [62].

On the other hand, the local community, which is also an important stakeholder of tourist activities, may face various problems that seemingly do not find a direct cause in tourism. These include the need for equal employment and promotion opportunities, but also access to natural resources (water, clean air, space) without restrictions generated by tourism.

The literature cites many examples of the negative effects of overtourism, including the consumption of excessive amounts of water or electricity by tourists, as a result of which the inhabitants of the destination feel their shortages. Overtourism is also known to generate excessive noise and garbage, which discourages residents of such neighborhoods, creating antagonism.

The concepts of development of tourist areas long known in the literature [110-112] notice the discussed problems, identifying them during the phase of intensive expansion of tourism. At that time, new infrastructure is created, the owners of which are usually no longer local residents, but external investors, often owners of hotels or restaurant chains. The loss of income caused by the decreased interest of tourists in the offer of local farms in favor of new infrastructure causes, with time, the local population to lose the possibility of making a living from tourism; in the best case, it becomes a human resource for new tourist investments (and even that is not guaranteed).

Sustainable values embedded in the business model should initiate the implementation of a management approach that solves the problems generated by tourism. Awareness of their occurrence should create responsibility of the company toward stakeholders, regardless of whether they report problems or not. However, an important element of sustainable value in health tourism enterprises should also be a preventive function in case of disasters caused by health, epidemic, terrorist, and military crises. The enterprise resources accumulated in the implementation of sustainable values should include con- 
tingency plans and material resources to reposition the business to provide assistance consistent with the needs of the state healthcare system.

The experience of crises caused by the COVID-19 pandemic will probably force the governments of many countries to create infrastructural, human, material, and financial reserves in case of further health crises. Health tourism enterprises can be part of such reserves, which will probably involve greater integration of these units into the healthcare system and, at the same time, greater state support toward tourism and treatment facilities.

The breakdown of sustainable values in spa enterprises, presented in Figure 3 in the context of their important role during the COVID-19 pandemic, shows the structure of the value generated, offered and captured by the enterprise. However, this is not all, as it is also important to locate the sustainable value component in the model and to identify the relationships with the other components.

Table 5 proposes a new approach to the business model dedicated to tourism and medical companies, which uses the value triple bottom line and the tenth component of the model, which is activated when the company responds to a crisis situation. The presented transformation of the business model (SusHT-CANVAS+) includes the component of crisis management and critical actions. The additional component is placed between the cost structure and revenue streams components, as this activity will be particularly related to both components; it is directly connected to sustainable value (Sv), which in a crisis situation, becomes a catalyst for change and crisis management, and in a non-crisis situation (i.e., pre-crisis), initiates the company's readiness to defend itself against the crisis situation. On the one hand, revenues are increased thanks to state subsidies, but on the other hand, maintaining readiness to respond to a crisis situation generates costs or requires the creation of reserves.

It is also important to place the sustainable value in close relation with the other value groups but keep them separate from each other. This emphasizes the importance of this group of values in the whole model, and at the same time, makes it possible to create relationships between the components and the whole set of values or individual values (i.e., with the sustainable value captured by the company and the value offered to customers).

The sustainable value has close relationships with the components gathered on the left side of the model. The relationship with key partners are related to the inclusion in this group of state bodies at local and supra-local levels, which in the case of a crisis, is the first initiator of emergency actions as well as a source of additional revenue related to the funding of these actions. On the other hand, the close relation between the sustainable value and the key actions undertaken by the company are indirect, as these actions are key, precisely after initiating changes related to the change of the activity profile from tourism and treatment to prevention and rescue. An additional relationship is the linking of sustainable value to key resources, the potential of which needs to be augmented with additional material or potential medical staff. This is not about hiring additional medics but initiating connections between enterprise resources and health system resources.

Table 5 exemplifies such a business model dedicated to health tourism and medical tourism enterprises. The SusHT-CANVAS+ model has the potential to adapt to a crisis situation by excluding the components on its right side, i.e., distribution channels, customer relationships, or customer segments, because, as the experience of the COVID-19 pandemic shows, in such situations, these components lose their importance in the model and sustainable value gains importance. 
Table 5. Scheme of business model, SusHT-CANVAS. Sources: Own study.

\begin{tabular}{|c|c|c|c|c|c|c|}
\hline \multicolumn{7}{|c|}{ The Health Tourism Business Model (SusHT-CANVAS) } \\
\hline Key Partners & Key Activities & & Extended Value Proposition & & Relations with the Clients & Customer Segments \\
\hline \multirow{4}{*}{$\begin{array}{ll}- & \text { National insurers } \\
- & \text { Local, regional and } \\
& \text { national administration } \\
- & \text { Suppliers of raw } \\
& \text { materials } \\
- & \text { Cooperating entities } \\
& \text { (outsourcing of } \\
& \text { gastronomy, treatments) } \\
- & \text { Coopetition entities, } \\
& \text { including competitors } \\
& \text { (advertisement) } \\
- & \text { Travel agencies }\end{array}$} & \multirow{4}{*}{$\begin{array}{ll}- & \begin{array}{l}\text { Health resort treatment } \\
\text { (diagnostics, program, }\end{array} \\
\text { treatment, education, } \\
\text { health effect) } \\
-\quad \begin{array}{l}\text { Spa and wellness and } \\
\text { sport services }\end{array} \\
-\quad \begin{array}{l}\text { Accommodation and } \\
\text { catering services }\end{array} \\
-\quad \text { Tourist services } \\
-\quad \text { Optimization of } \\
\text { activities and } \\
\text { programming of } \\
\text { treatments } \\
-\quad \begin{array}{l}\text { Preventive and rescue } \\
\text { actions }\end{array}\end{array}$} & $\begin{array}{l}\text { Value Proposition for the } \\
\text { Customer (the Core) }\end{array}$ & $\begin{array}{c}\text { Sustainability } \\
\text { Value Proposition }\end{array}$ & $\begin{array}{l}\text { Value Captured by the } \\
\text { Enterprise }\end{array}$ & \multirow{4}{*}{$\begin{array}{l}\text { - The spa patient as a } \\
\text { "best guest" or "family } \\
\text { guest" } \\
\text { - Health, physical, } \\
\text { emotional (mental, } \\
\text { spiritual) safety } \\
\text { - Creating an emotional } \\
\text { bond (photos, films, } \\
\text { animation, trips) }\end{array}$} & \multirow{4}{*}{$\begin{array}{l}\text { Segmentation criterion: } \\
\text { - Function (patient with } \\
\text { medical referral, tourist } \\
\text { without referral) } \\
\text { - Purpose of stay } \\
\text { (treatment, prophylaxis, } \\
\text { leisure, sport, beauty, } \\
\text { etc.) }\end{array}$} \\
\hline & & $\begin{array}{l}\text { Health effect, relax, } \\
\text { improved beauty and sports } \\
\text { results, weight loss, positive } \\
\text { emotions, and memories }\end{array}$ & $\begin{array}{l}\text { Employment of the local } \\
\text { community, promoting local } \\
\text { culture and heritage, } \\
\text { limiting the company's } \\
\text { impact on the natural } \\
\text { environment and } \\
\text { community, emergency } \\
\text { medical and housing } \\
\text { reserve }\end{array}$ & $\begin{array}{l}\text { Profits, increasing the } \\
\text { company's assets, } \\
\text { developing relationships } \\
\text { with clients and contractors, } \\
\text { satisfaction with the social } \\
\text { mission }\end{array}$ & & \\
\hline & & Key Resources & & Channels & & \\
\hline & & 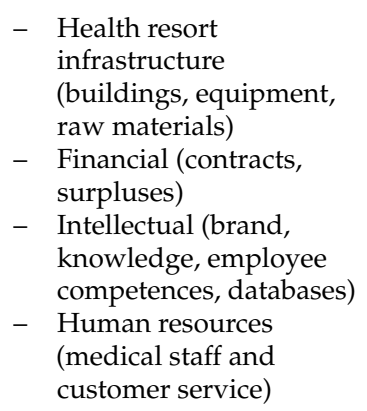 & 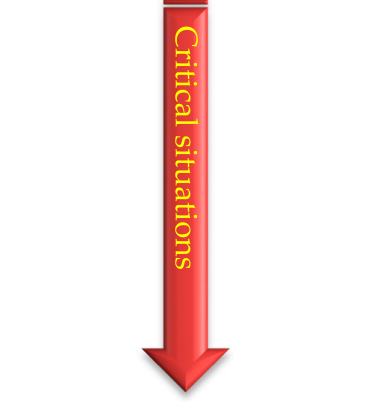 & $\begin{array}{ll}\text { - } & \text { Direct communication } \\
& \text { with tourists } \\
\text { - } & \text { Health clinics in the } \\
& \text { place of residence of } \\
& \text { potential clients } \\
- & \text { Internet, websites, social } \\
& \text { media, TV, RTV, press } \\
- & \text { TV programs promoting } \\
& \text { the effects of treatment } \\
- & \text { Travel agencies, tour } \\
& \text { operators }\end{array}$ & & \\
\hline \multicolumn{2}{|c|}{ Cost Structure } & \multicolumn{3}{|c|}{ Crisis Management and Critical Activities } & \multicolumn{2}{|c|}{ Revenue Streams } \\
\hline \multicolumn{2}{|c|}{$\begin{array}{l}\text { - Employment (medical and non-medical personnel) } \\
\text { - Readiness of accommodation and catering } \\
\text { - Treatments and medical care } \\
\text { - } \text { Maintenance of medicine infrastructure } \\
\text { - Healing natural resources } \\
\text { - Energy, water and disposal of waste } \\
\text { - } \\
\text { - Pnimation, entertainment, education } \\
\text { - } \quad \text { Cost of lost orders }\end{array}$} & \multicolumn{3}{|c|}{$\begin{array}{l}\text { Development and implementation of emergency action plans to reduce the local effects } \\
\text { of health, environmental, and terrorist disasters } \\
\text { - Preparing the enterprise for a quick change of the business profile as part of coordinated } \\
\text { rescue operations on a regional scale (change of the tourist and treatment base into } \\
\text { immediate infectious wards and a quarantine or evacuation zone) } \\
\text { - Creating a reserve of epidemiological and energy security measures (coveralls, } \\
\text { disinfection agents, power generators) }\end{array}$} & \multicolumn{2}{|c|}{$\begin{array}{l}\text { Breakdown criterion: market segments } \\
-\quad \text { Contracts with insurers } \\
-\quad \text { Individual and group patients and tourists } \\
\text { - Entrepreneurs and sports organizations } \\
\text { Breakdown criterion: types of services } \\
-\quad \text { Treatments, diagnostics and medical care } \\
-\quad \text { Accommodation, food and education } \\
-\quad \text { Sport, recreation and tourism attractions } \\
-\quad \text { Sale of products (bottled water, raw materials) } \\
\text { In an emergency: government subsidies }\end{array}$} \\
\hline
\end{tabular}


However, the essence of transforming the business model within the framework of sustainable value should be opening access to such emergency solutions. It is about sharing all knowledge in this area and striving to make this scope of the business model functioning an open innovation, and perhaps even more to make the transformed business model an open business model. Successful examples of such solutions have been discussed previously [79,82-85].

\section{Conclusions}

The book, Cannibals with Forks: the Triple Bottom Line (TBL) of 21st Century Business [95] by J. Elkington, a proponent of the TBL concept, is based on a quotation from a poem by a Polish poet who went down in history thanks to the popularity of this single question: "Is it progress if a cannibal uses a fork?". At the same time, this quotation sums up the doubts about the effectiveness of the efforts made so far to develop concepts aimed at saving the world from ecological destruction. It makes one wonder about the sense of idealistic and idle concern for the natural environment. At the same time, however, it makes us aware of the need to introduce mental and organizational changes that are necessary to be implemented at this very moment in human history.

The author's proposal is a permanent modification of business models in tourism enterprises in which an important element of generated value is sustainable value as well as crisis management and critical actions, undertaken in situations when tourism is impossible and the need to help the local people is indispensable. An example is the presented assumptions of the SusHT-CANVAS+ model.

The presented concept of the SusHT-CANVAS+ model has many limitations. One of them is that there is no indication of where the model is integrated into the health care system. This is due to the separation nature of systems in different countries. In Poland, health resort enterprises acting as tourist and treatment facilities are a reserve base in case of the need to isolate the population and for emergency treatment; therefore, they are one of the last links activated within emergency actions in an epidemiological crisis situation. Their activities are financed from the reserve funds of the state budget.

Another limitation is the scope of their research. The period of the pandemic for many of these companies has not been a time to stop all business processes, but a time for intensive implementation of the social mission. Therefore, at this point, it is worth expressing gratitude to the managers who agreed to take part in the study for the opportunity to share their experiences.

Finally, it is worth returning to the work of the poet whose question leads us to doubt the effectiveness of the actions taken so far within the framework of sustainable development. His tombstone bears an engraved aphorism he authored, reading: "It is not easy to live after death. Sometimes you have to spend your whole life doing it." The perversity of this sentence can hardly be overlooked. If modern mankind does not take care of the following generations during its lifetime, it is vain to expect that it will live after death in the heartfelt memory of its descendants.

Funding: This paper was published as part of the research project "A business model for health resort enterprises" No. 2017/25/B/HS4/00301, supervised and financed by the National Science Center in Poland and as part of statutory research ROZ 1: 13/010/BK_21/0057 at the Silesian University of Technology, Faculty of Organization and Management, and as part of grant 13/010/RGJ21/0054 from the Rector of the Silesian University of Technology.

Institutional Review Board Statement: Not applicable.

Informed Consent Statement: Not applicable.

Acknowledgments: The author would like to thank Aleksandra Wierzbicka for help in the implementation of field research. 
Conflicts of Interest: The author declares no conflict of interest. The funders had no role in the design of the study; in the collection, analyses, or interpretation of data; in the writing of the manuscript, or in the decision to publish the results.

\section{References}

1. Kapczyński, A.; Szromek, A.R. Hypotheses concerning the development of Polish spas in the years 1949-2006. Tour. Manag. 2008, 29, 1035-1037. [CrossRef]

2. Smith, M.; Puczkó, L. Historical overview. In Health and Wellness Tourism; Smith, M., Puczkó, L., Eds.; Routledge: New York, NY, USA, 2009.

3. Rodríguez-Antón, J.M.; Alonso-Almeida, M.d.M. COVID-19 Impacts and Recovery Strategies: The Case of the Hospitality Industry in Spain. Sustainability 2020, 12, 8599. [CrossRef]

4. Gössling, S.; Scott, D.; Hall, C.M. Pandemics, tourism and global change: A rapid assessment of COVID-19. J. Sustain. Tour. 2020, 29, 1-20. [CrossRef]

5. Nosratabadi, S.; Mosavi, A.; Shamshirband, S.; Zavadskas, E.K.; Rakotonirainy, A.; Wing Chau, K. Sustainable Business Models: A Review. Sustainability 2019, 11, 1663. [CrossRef]

6. Delft, S.; Zhao, Y. Business models in process industries: Emerging trends and future research. Technovation 2020, 7, 102195. [CrossRef]

7. Diaconu, M.; Dutu, A. Business model in the hospitality industry, from traditional to open innovation. Sci. Bull. Econ. Sci. 2017, 16, 3-10.

8. Langvinienè, N.; Daunoravičiūtè, I. Factors influencing the success of business model in the hospitality service industry. Procedia Soc. Behav. Sci. 2015, 213, 902-910. [CrossRef]

9. Falencikowski, T. Model biznesu dla Polski współczesnym wyzwaniem gospodarczym. Studia I Pr. Kol. Zarzadzania I Finans.Szkoła Główna Handlowa 2012, 115, 38-54.

10. Osterwalder, A.; Pigneur, Y. Business Model Generation: A Handbook for Visionaries, Game Changers, and Challengers; John Wiley \& Sons: Hoboken, NJ, USA, 2010; p. 59.

11. Chesbrough, H.W. Open Business Models: How to Thrive in the New Innovation Landscape; Harvard Business Press: Boston, MA, USA, 2006; pp. 1-272.

12. Westa, J.; Salterb, A.; Vanhaverbekecef, W.; Chesbrough, H. Open Innovation: The Next Decade. Res. Policy 2014, 43, 805-811. [CrossRef]

13. Seidenstricker, S.; Scheuerle, S.; Linder, C. Business Model Prototyping-Using the Morphological Analysis to Develop New Business Models. Procedia Soc. Behav. Sci. 2014, 148, 102-109. [CrossRef]

14. Al-Debei, M.; El-Haddadeh, R.; Avison, D. Defining the Business Model in the New World of Digital Business. In Proceedings of the Fourteenth Americas Conference on Information Systems, Toronto, ON, Canada, 14-17 August 2008.

15. Costa Climent, R.; Haftor, D.M. Value creation through the evolution of business model themes. J. Bus. Res. 2021, 122, 353-361. [CrossRef]

16. Bellman, R.; Clark, C.E.; Malcolm, D.G.; Craft, C.J.; Ricciardi, F.M. On the Construction of a Multi-Stage, Multi-Person Business Game. Oper. Res. 1957, 5, 457-608. [CrossRef]

17. Lang, F. Insurance research. J. Mark. 1947, 12, 66-71. [CrossRef]

18. Chesbrough, H.; Rosenbloom, R. The role of the business model in capturing value from innovation: Evidence from Xerox Corporation's technology spin-off companies. For. Ind. 2002, 11, 529-555. [CrossRef]

19. Wit, B. Ekologistyka w Systemie Zarzadzania Odpadami Niebezpiecznymi; Towarzystwo Naukowe Organizacji i Kierowania: Toruń, Poland; Stowarzyszenie Wyższej Użyteczności Dom Organizatora: Torun, Poland, 2016; p. 138.

20. Obłój, K. Tworzywo Skutecznych Strategii; PWE: Warsaw, Poland, 2002; p. 97.

21. Teece, D. Business models and dynamic capabilities. Long Range Plan. 2018, 51, 40-49. [CrossRef]

22. Prendeville, S.; Bocken, N. Sustainable Business Models through Service Design. Procedia Manuf. 2017, 8, 292-299. [CrossRef]

23. Johnson, W.; Christensen, C.; Kagerman, H. Reinventing Your Business Model. Harv. Bus. Rev. 2008, 86, 57-68.

24. Keen, P.; Quereshi, S. Organizational Transformation through Business Models: A Framework for Business Model Design. Inf. Syst. Quant. Anal. Fac. Proc. Present. 2006, 43, 1-10.

25. Brzóska, J. Model biznesowy—współczesna forma modelu organizacyjnego zarządzania przedsiębiorstwem. Organ. I Zarządzanie Kwart. Nauk. 2009, 2, 5-23.

26. Auer, C.; Follack, M. Using Action Research for Gaining Competitive Advantage out of the Internet's Impact on Existing Business Models. In Proceedings of the 15th Bled Electronic Commerce Conference eReality: Constructing the eEconomy, Bled, Slovenia, 17-19 June 2002; pp. 767-784.

27. Pateli, A.; Giaglis, G. Technology Innovation-induced Business Model Change: A Contingency Approach. J. Organ. Chang. Manag. 2005, 18, 167-183. [CrossRef]

28. Senge, P.M.; Sterman, J.D. System Thinking and Organizational Learning; Acting Locally and Thinking Globally in the Organization of the Future. In Modeling for Learning Organizations; Morecroft, J.D., Sterman, J.D., Eds.; Productivity Press: Portland, OR, USA, 1994; pp. 195-216. 
29. Morris, M.; Schindehutte, M.; Allen, J. The entrepreneur's business model: Toward a unified perspective. J. Bus. Res. 2005, 58, 726-735. [CrossRef]

30. Amit, R.; Zott, C. Value creation in e-business. Strateg. Manag. J. 2001, 22, 493-520. [CrossRef]

31. Amit, R.; Zott, C. Creating value through business model innovation. MIT Sloan Manag. Rev. 2012, 53, 41-49.

32. Amit, R.; Zott, C. Crafting business architecture: The antecedents of business model design. Strateg. Entrep. J. 2015, 9, 331-350. [CrossRef]

33. Souto, J. Business model innovation and business concept innovation as the context of incremental innovation and radical innovation. Tour. Manag. 2015, 51, 142-155. [CrossRef]

34. Grabowska, S. Modelowanie Procesów Biznesowych w Działalności Przedsiębiorstw Turystycznych w Warunkach Konkurencyjności. Ph.D. Thesis, Silesian University of Technology, Gliwice, Poland, 2013.

35. Herman, K.; Szromek, A.R. Przedsiębiorstwo Turystyczne w ujęciu Modelowym. Model Biznesu w Przedsiębiorstwie Turystyki Dziedzictwa Przemysłowego; Wydawnictwo Politechniki Ślaskiej: Gliwice, Poland, 2018; p. 36.

36. Szromek, A.R. Model of Business Relations in Spa Tourism Enterprises and Their Business Environment. Sustainability 2020, 12 4941. [CrossRef]

37. Strulak-Wójcikiewicz, R.; Wagner, N.; Łapko, A.; Hacia, E. Applying the Business Model Canvas to Design the E-platform for Sailing Tourism. Procedia Comput. Sci. 2020, 176, 1643-1651. [CrossRef]

38. Perić, M.; Vitezić, V.; Đurkin Badurina, J. Business models for active outdoor sport event tourism experiences. Tour. Manag. Perspect. 2019, 32, 100561. [CrossRef]

39. Miguéns, J.; Baggio, R.; Costa, C. Social media and Tourism Destinations: TripAdvisor Case Study. Adv. Tour. Res. 2008, 26, 1-6.

40. Inversini, A.; Xiang, Z.; Fesenmaier, D.R. New meDia in Travel and Tourism Communication: Toward a New Paradigm. Available online: https:/ /inversini.files.wordpress.com/2008/01/27_cont_9783110266535_inversini_xiang_fesenmaier1.pdf (accessed on 4 March 2021).

41. Bodenau, A. Innovative Value of Sustainable Tourism Practices. Innovation and Value Creation in Experience Based Tourism. In Proceedings of the 22nd Nordic Symposium in Tourism and Hospitality Research, Bodø/Lofoten, Norway, 24-27 September 2013; pp. 23-25.

42. Prebensen, N.; Dahl, J. Value co-creation significance of tourist resources. Ann. Tour. Res. 2013, 42, 240-261. [CrossRef]

43. OECD. Managing tourism development for sustainable and inclusive recovery. In OECD Tourism Papers; OECD Publishing: Paris, France, 2021; pp. 1-61.

44. Global Sustainable Tourism Council. GSTC Criteria for Hotels. GSTC Criteria for Tour Operators. GSTC Criteria for Destinations. 2019. Available online: http://www.gstcouncil.org/gstc-criteria/ (accessed on 1 August 2019).

45. Szromek, A.R. The Sustainable Business Model of Spa Tourism Enterprise-Results of Research Carried Out in Poland. J. Open Innov. Technol. Mark. Complex. 2021, 7, 73. [CrossRef]

46. Kenig-Witkowska, M.M. Międzynarodowe Prawo Środowiska; Wolters Kluwer Polska Sp. z o.o.: Warszawa, Poland, 2011.

47. United Nations. Proceedings of the United Nations Conference on Environment and Development, Rio de Janeiro, Brazil, 3-14 June 1992; pp. 1-492. Available online: https:/ / undocs.org/en/A/CONF.151/26/Rev.1(vol.I) (accessed on 4 March 2021).

48. United Nations. Proceedings of the AGENDA 21, United Nations Conference on Environment \& Development, Rio de Janerio, Brazil, 3-14 June 1992; pp. 1-351. Available online: https:/ / sustainabledevelopment.un.org/content/documents/Agenda21.pdf (accessed on 4 March 2021).

49. Mensah, J. Sustainable development: Meaning, history, principles, pillars, and implications for human action: Literature review. Cogent Soc. Sci. 2019, 5, 1653531. [CrossRef]

50. Ukaga, U.; Maser, C.; Reichenbach, M. Sustainable development: Principles, frameworks, and case studies. Int. J. Sustain. High Educ. 2011, 12. [CrossRef]

51. Hák, T.; Janoušková, S.; Moldan, B. Sustainable development goals: A need for relevant indicators. Ecol. Indic. 2016, 60, 565-573. [CrossRef]

52. Brodhag, C.; Taliere, S. Sustainable development strategies: Tools for policy coherence. Nat. Resour. Forum 2006, 30, 136-145. [CrossRef]

53. Diesendorf, M. Sustainability and sustainable development. In Sustainability: The Corporate Challenge of the 21st Century; Dunphy, D., Benveniste, J., Griffiths, A., Sutton, P., Eds.; Allen \& Unwin: Sydney, Australia, 2000; Volume 2, pp. 19-37.

54. Evers, B.A. Why Adopt the Sustainable Development Goals? The Case of Multinationals in the Colombian Coffee and Extractive Sector. Master's Thesis, Erasmus University Rotterdam, Rotterdam, The Netherlands, 2018.

55. Arefiev, N.; Garmanov, V.; Bogdanov, V.; Ryabov, Y.; Terleev, V.; Badenko, V. A Market Approach to the Evaluation of the Ecological-Economic Damage Dealt to the Urban Lands. Procedia Eng. 2015, 117, 26-31. [CrossRef]

56. Saith, A. From universal values to millennium development goals: Lost in translation. Dev. Chang. 2006, 37, 1167-1199. [CrossRef]

57. Geissdoerfer, M.; Bocken, N.M.; Hultink, E.J. Design thinking to enhance the sustainable business modelling process-A workshop based on a value mapping process. J. Clean. Prod. 2016, 135, 1218-1232. [CrossRef]

58. Feng, J.; Liu, Z.; Feng, L. Identifying opportunities for sustainable business models in manufacturing: Application of patent analysis and generative topographic mapping. Sustain. Prod. Consum. 2021, 27, 509-522. [CrossRef]

59. Boons, F.; Lüdeke-Freund, F. Business models for sustainable innovation: State of the art and steps towards a research agenda. J. Clean. Prod. 2013, 45, 9-19. [CrossRef] 
60. Lüdeke-Freund, F.; Carroux, S.; Joyce, A.; Massa, L.; Breuer, H. The sustainable business model pattern taxonomy—45 patterns to support sustainability-oriented business model innovation. Sustain. Prod. Consum. 2018, 15, 145-162. [CrossRef]

61. Geissdoerfer, M.; Vladimirova, D.; Evans, S. Sustainable business model innovation: A review. J. Clean. Prod. 2018, 198, 401-416. [CrossRef]

62. Nidumolu, R.; Prahalad, C.K.; Rangaswami, M.R. Why sustainability is now the key driver of innovation. Harv. Bus. Rev. 2009, $87,56-64$.

63. Osterwalder, A. The Business Model Ontology. A Proposition in a Design Science Approach. Ph.D. Thesis, Université de Lausanne, Lausanne, Switzerland, 2004. Available online: http://www.hec.unil.ch/aosterwa/PhD/Osterwalder_PhD_BM_Ontology.pdf (accessed on 2 March 2021).

64. Doganova, L.; Eyquem-Renault, M. What do business models do? Innovation devices in technology entrepreneurship. Res. Policy 2009, 38, 1559-1570. [CrossRef]

65. Stubbs, W.; Cocklin, C. Conceptualizing a sustainability business model. Organ. Environ. 2008, 21, 103-127. [CrossRef]

66. Abdelkafi, N.; Tauscher, K. Business models for sustainability from a system dynamics perspective. Organ. Environ. 2016, 29, 74-96. [CrossRef]

67. Thorisdottir, T.S.; Johannsdottir, L. Sustainability within Fashion Business Models: A Systematic Literature Review. Sustainability 2019, 11, 2233. [CrossRef]

68. Jabłoński, A. Scalability of Sustainable Business Models in Hybrid Organizations. Sustainability 2016, 8, 194. [CrossRef]

69. Giannoni, C.; Alarcón, L.F.; Vera, S. Diagnosis of Sustainable Business Strategies Implemented by Chilean Construction Companies. Sustainability 2018, 10, 82. [CrossRef]

70. Lemus-Aguilar, I.; Morales-Alonso, G.; Ramirez-Portilla, A.; Hidalgo, A. Sustainable Business Models through the Lens of Organizational Design: A Systematic Literature Review. Sustainability 2019, 11, 5379. [CrossRef]

71. Bocken, N.M.P.; Short, S.W.; Rana, P.; Evans, S. A literature and practice review to develop sustainable business model archetypes. J. Clean. Prod. 2014, 65, 42-56. [CrossRef]

72. Ritala, P.; Huotari, P.; Bocken, N.; Albareda, L.; Puumalainen, K. Sustainable business model adoption among S\&P 500 firms: A longitudinal content analysis study. J. Clean. Prod. 2018, 170, 216-226.

73. Urbinati, A.; Franzò, S.; Chiaroni, D. Enablers and Barriers for Circular Business Models: An empirical analysis in the Italian automotive industry. Sustain. Prod. Consum. 2021, 27, 551-566. [CrossRef]

74. Stahel, W.R. Policy for material efficiency-sustainable taxation as a departure from the throwaway society. Philos. Trans. R. Soc. A Math. Phys. Eng. Sci. 2013, 371, 20110567. [CrossRef]

75. Chiaroni, D.; Urbinati, A. Circular Economy Business Models: Towards a new taxonomy of the degree of circularity. In Proceedings of the XXVII edition of the Annual Scientific Meeting of the Italian Association of Management Engineering (AiIG), Higher Education and Socio-Economic Development, Bergamo, Italy, 13-14 October 2016.

76. Zucchella, A.; Previtali, P. Circular business models for sustainable development: A "waste is food"restorative ecosystem. Bus. Strategy Environ. 2019, 28, 274-285. [CrossRef]

77. Mostaghel, R.; Chirumalla, K. Role of customers in circular business models. J. Bus. Res. 2021, 127, 35-44. [CrossRef]

78. Evans, S.; Vladimirova, D.; Holgado, M.; Van Fossen, K.; Yang, M.; Silva, E.; Barlow, C. Business model innovation for sustainability: Towards a unified perspective for creation of sustainable business models. Bus. Strat. Env. 2017. [CrossRef]

79. Yun, J.J. Business Model Design Compass. Open Innovation Funnel to Schumpeterian New Combination Business Model Developing Circle; Management for Professionals; Springer: Berlin/Heidelberg, Germany, 2017; pp. 1-248.

80. Wannakrairoj, W.; Velu, C. Productivity growth and business model innovation. Econ. Lett. 2021, 199, 109679. [CrossRef]

81. Bhatti, S.H.; Santoro, G.; Khan, J.; Rizzato, F. Antecedents and consequences of business model innovation in the IT industry. J. Bus. Res. 2021, 123, 389-400. [CrossRef]

82. Aziz, E.; Mustapha, H.; Jamila, E.A. A bibliometric study of the recent advances in open innovation concept. Procedia Comput. Sci. 2020, 175, 683-688. [CrossRef]

83. Chesbrough, H.W. Business model innovation: It's not just about technology anymore. Strategy Lead. 2007, 35, 12-17. [CrossRef]

84. Yun, J.J.; Zhao, X. Business model innovation through a rectangular compass: From the perspective of open innovation with mechanism design. J. Open Innov. Technol. Mark. Complex. 2020, 6, 131. [CrossRef]

85. Yun, J.J.; Zhao, X.; Wu, J.; Yi, J.C.; Park, K.; Jung, W. Business model, open innovation, and sustainability in car sharing industry-Comparing three economies. Sustainability 2020, 12, 1883. [CrossRef]

86. Agarwal, R.; Mittal, N.; Patterson, E.; Giorcelli, M. Evolution of the Indian LPG industry: Exploring conditions for public sector business model innovation. Res. Policy 2021, 50, 104196. [CrossRef]

87. Harries, J.E.; Brindley, H.E.; Sagoo, P.J.; Bantges, R.J. Increases in greenhouse forcing inferred from the outgoing longwave radiation spectra of the Earth in 1970 and 1997. Nature 2001, 410, 355-357. [CrossRef]

88. Hiteva, R.; Foxon, T.J. Beware the value gap: Creating value for users and for the system through innovation in digital energy services business models. Technol. Forecast. Soc. Chang. 2021, 166, 120525. [CrossRef]

89. Schaltegger, S.; Hansen, E.; Lüdeke-Freund, F. Business cases for sustainability and the role of business model innovation. Int. J. Innov. Sustain. Dev. 2012, 6, 95-119. [CrossRef]

90. Szromek, A.R.; Naramski, M. A Business Model in Spa Tourism Enterprises: Case Study from Poland. Sustainability 2019, 11, 2880. [CrossRef] 
91. Joyce, A.; Paquin, R. The triple layered business model canvas: A tool to design more sustainable business models. J. Clean. Prod. 2016, 135, 1484. [CrossRef]

92. Jang, Y.; Ahn, Y.; Park, M.; Lee, H.-S.; Kwon, N. Business Models and Performance of International Construction Companies. Sustainability 2019, 11, 2575. [CrossRef]

93. Butler, R.W.; Szromek, A.R. Incorporating the Value Proposition for Society with Business Models of Health Tourism Enterprises. Sustainability 2019, 11, 6711. [CrossRef]

94. Yang, M.; Evans, S.; Vladimirova, D.; Rana, P. Value uncaptured perspective for sustainable business model innovation. J. Clean. Prod. 2016, 140, 1794-1804. [CrossRef]

95. Elkington, J. Cannibals with Forks: The Triple Bottom Line of 21st Century Business; Capstone: Oxford, UK, 1999 ; ISBN 9780865713925.

96. Silvius, A.J.G.; Schipper, R. A conceptual model for exploring the relationship between sustainability and project success. Procedia Comput. Sci. 2015, 64, 334-342. [CrossRef]

97. Homrich, A.S.; Theodoro, D.S.; Monteiro de Carvalho, M. PSS creating business for sustainability: The Brazilian Olive Oil case in Mantiqueira Community. Procedia CIRP 2017, 64, 405-410. [CrossRef]

98. Krechovská, M.; Tausl Prochazkova, P. Sustainability and its Integration into Corporate Governance Focusing on Corporate Performance Management and Reporting. Procedia Eng. 2014, 69, 1144-1151. [CrossRef]

99. Waite, M. SURF Framework for a Sustainable Economy. J. Manag. Sustain. 2013, 3, 25. [CrossRef]

100. Ying, T.; Wang, K.; Liu, X.; Wen, J.; Goh, E. Rethinking game consumption in tourism: A case of the 2019 novel coronavirus pneumonia outbreak in China. Tour. Recreat. Res. 2020. [CrossRef]

101. Yang, M.; Vladimirova, D.; Rana, P.; Evans, S. Sustainable value analysis tool for value creation. Asian J. Manag. Sci. Appl. 2014, 1, 312-332. [CrossRef]

102. Yang, M.; Rana, P.; Evans, S. Product service system (PSS) life cycle value analysis for sustainability. In Proceedings of the 6th International Conference on Design and Manufacture for Sustainable Development (ICDMSD), New York, NY, USA, 6-7 September 2013.

103. Jovane, F.; Yoshikawa, H.; Alting, L.; Boër, C.R.; Westkamper, E.; Williams, D.; Tseng, M. The incoming global technological and industrial revolution towards competitive sustainable manufacturing. CIRP Ann. Manuf. Technol. 2008, 57, 641-659. [CrossRef]

104. Statistisc Poland. Działalność Lecznicza Zakładów Lecznictwa Uzdrowiskowego i Stacjonarnych Zakładów Rehabilitacji Leczniczej w 2018 r. Główny Urząd Statystyczny 2019. pp. 1-5. Available online: https://stat.gov.pl/download/gfx/ portalinformacyjny/pl/defaultaktualnosci/5513/12/3/1/dzialalnosc_lecznicza_zakladow_lecznictwa_uzdrowiskowego_i_ stacjonarnych_w_2018.pdf (accessed on 17 March 2021).

105. Ministerstwo Zdrowia Rzeczypospolitej Polskiej. 2021. Available online: http:/ $/$ www2.mz.gov.pl $/ \mathrm{wwwmz} / \mathrm{index}$ ?mr=m8\&ms= $698 \& m L=p 1 \& m i=698 \& m x=0 \& m a=13915$ (accessed on 24 February 2021).

106. Skare, M.; Soriano, D.R.; Porada-Rochoń, M. Impact of COVID-19 on the travel and tourism industry. Technol. Forecast. Soc. Chang. 2021, 163, 120469. [CrossRef]

107. Bertella, G. Re-thinking sustainability and food in tourism. Ann. Tour. Res. 2020, 84, 103005. [CrossRef] [PubMed]

108. Tew, P.J.; Lu, Z.; Tolomiczenko, G.; Gellatly, J. SARS: Lessons in strategic planning for hoteliers and destination marketers. Int. J. Contemp. Hosp. Manag. 2008, 20, 332-346.

109. Silesian University of Technology. The Silesian University of Technology is Developing a Decontamination Gate for Medical Personnel. Available online: https: / / www.polsl.pl/Lists / AktualnosciUczelniane/PokazWiadomosc.aspx?WebPartTitle= ListaWiadomosci\&Page=1\&WebPartTitle2=Wiadomosc\&Filter1Field2=Identyfikator\&Filter1Value2=3228 (accessed on 17 March 2021).

110. Butler, R.W. The concept of a Tourism Area Life Cycle of Evolution. Can. Geographer. 1980, 24, 5-12.

111. Plog, S.C. Why Destination Areas Rise and Fall in Popularity. Cornell Hotel Restaur. Adm. Q. 1974, 14, 55-58. [CrossRef]

112. Plog, S.C. Why Destination Areas Rise and Fall in Popularity. Cornell Hotel Restaur. Adm. Q. 2001, 42, 13-24. [CrossRef] 